\title{
Removing Phenols from Post-Processing Wastewater Originating from Underground Coal Gasification Using Coagulation-Flocculation and the $\mathrm{H}_{2} \mathrm{O}_{2} / \mathrm{UV}$ Process
}

\author{
Maciej Thomas $^{1}$, Dariusz Zdebik ${ }^{2 *}$, Ewa Niewiara ${ }^{3}$ \\ ${ }^{1}$ Chemiqua Company, Kraków, Poland \\ ${ }^{2}$ Central Mining Institute, Department of Water Protection, Katowice, Poland \\ ${ }^{3}$ AGH University of Science and Technology, Faculty of Materials Science and Ceramics, Kraków, Poland
}

Received: 27 June 2017

Accepted: 17 December 2017

\begin{abstract}
Our paper presents the possibility of phenol removal from post-processing wastewater originating from an experimental simulation of the underground coal gasification process carried out in the Barbara Experimental Mine in Mikołów, Poland. The application of initial coagulation-flocculation processes with iron(II), iron(III), aluminium, titanium(IV), and zirconium(IV) and anionic flocculant has allowed phenols removal from $7.9 \%\left(\mathrm{pH} 8, \mathrm{Zr}^{4+} 400 \mathrm{mg} / \mathrm{L}\right.$ ) to $22.2 \%$ (for $\mathrm{pH} 8, \mathrm{Fe}^{2+}$ 800 and $1,000 \mathrm{mg} / \mathrm{L}$ and for $\mathrm{pH} 8, \mathrm{Fe}^{3+} 1,000 \mathrm{mg} / \mathrm{L}$ ). The application of the coagulation-flocculation process and advanced oxidation in the $\mathrm{H}_{2} \mathrm{O}_{2} / \mathrm{UV}$ system resulted in a total reduction of phenolic concentrations in the treated wastewater by about $93 \%$ due to their reaction with $\mathrm{OH} \bullet$ radicals, resulting from the UV rays impact on $\mathrm{H}_{2} \mathrm{O}_{2}$.
\end{abstract}

Keywords: phenols, wastewater, underground coal gasification, coagulants, advanced oxidation processes, AOPs

\section{Introduction}

Contamination of the natural environment, especially of surface waters with organic compounds, is connected to the constantly progressing process of industrialization in the world. Phenols and theirs compounds are toxic substances that are frequently present in industrial wastewater from petrochemical processes, chemical processing of coal, and the production of polymer resins,

*e-mail: dzdebik@gig.eu pharmaceuticals, and more. Studies on effective methods of removal and degradation of phenolic compounds are important for protecting the natural environment against pollution [1]. In the wastewater originating from the refinery, phenols were found in the range $6-500 \mathrm{mg} / \mathrm{L}$, in coke-plant effluents $28-3,900 \mathrm{mg} / \mathrm{L}$, in wastewater from coal processing plants $9-6,800 \mathrm{mg} / \mathrm{L}$, and in wastewater from the petrochemical industry $2.8-1,200 \mathrm{mg} / \mathrm{L}$. In the case of wastewater from the production of pharmaceuticals, plastics, wood products, and paints, the concentration of phenols varied between 0.1 and $1,600 \mathrm{mg} / \mathrm{L}$ [2-3]. In wastewater from experimental 
coal gasification processes, the content of phenols was 11-3,090 mg/L and depended on the chemical composition of coal and the parameters of the gasification process [4-6]. Phenol is a toxic, carcinogenic, teratogenic, and potentially mutagenic compound and it is therefore one of the most important substances for which the U.S. Environmental Protection Agency (US EPA) has set a maximum emission limit of $0.5 \mathrm{mg} / \mathrm{L}$ [7-8]. For the same reasons, they determined a maximum phenols concentration in drinking water of $1 \mu \mathrm{g} / \mathrm{L}$. The conducted studies have shown that the use of chlorine to disinfect phenol-containing water leads to toxic 2-chlorophenol formation [9]. Phenols in concentrations over $2 \mathrm{mg} / \mathrm{L}$ are toxic to fish, and in concentrations from $10-100 \mathrm{mg} / \mathrm{L}$ cause the death of many aquatic organisms within 96 hours [10]. The removal of phenols from wastewater can be carried out by adsorption [11-12], extraction [13], reverse osmosis, and nanofiltration [14-15], perflation [16], and membrane distillation [17]. It is also possible to use chemical oxidation processes with ferrate(VI) and permanganate(VII) [18-19]. Wet air oxidation (WAO) and catalytic wet air oxidation (CWAO) processes are also used.

In the second case, high temperature, high pressure, and catalyst additives are used [20]. Especially interesting and undertaken by many researchers seems to be the application of advanced oxidation processes (AOPs), which use hydroxyl radicals $(\mathrm{OH} \bullet)$ formed in the reaction environment, which can react with most organic compounds, leading to their effective degradation. In addition to the classical Fenton method, its numerous modifications are used, such as: photo-Fenton or electroFenton processes, which usually lead to increased speed and final efficiency of the treatment process [21]. Among the methods of advanced oxidation, the $\mathrm{H}_{2} \mathrm{O}_{2} / \mathrm{UV}$ process is also used, whose advantage is that there is no need for the $\mathrm{Fe}(\mathrm{II})$ compounds presence to produce $\mathrm{OH} \bullet$ and consequently avoid the formation of hydrated sediments of $\mathrm{Fe}(\mathrm{II})$ and $\mathrm{Fe}(\mathrm{III})$ hydroxides due to alkalisation of wastewater after the process is complete. The use of

Table 1. Physicochemical parameters of post-processing wastewater originating from UCG.

\begin{tabular}{|c|c|c|}
\hline Parameter & Unit & Value \\
\hline $\mathrm{pH}$ & - & 7.5 \\
\hline Electrical conductivity at $20^{\circ} \mathrm{C}$ & $\mu \mathrm{S} / \mathrm{cm}$ & 4,180 \\
\hline Absorbance (UV254, dilution 1:40) & - & 0.437 \\
\hline Turbidity & NTU & 171 \\
\hline Colour & $\mathrm{mg} \mathrm{Pt} / \mathrm{L}$ & 3,320 \\
\hline Chemical oxygen demand (COD) & $\mathrm{mg} \mathrm{O}_{2} / \mathrm{L}$ & 3,050 \\
\hline Total organic carbon (TOC) & $\mathrm{mg} / \mathrm{L}$ & 910 \\
\hline Total nitrogen & $\mathrm{mg} / \mathrm{L}$ & 580 \\
\hline Sulfides & $\mathrm{mg} / \mathrm{L}$ & 0.81 \\
\hline Phenols & $\mathrm{mg} / \mathrm{L}$ & 1,360 \\
\hline
\end{tabular}

the advanced $\mathrm{H}_{2} \mathrm{O}_{2} / \mathrm{UV}$ oxidation process allows for the degradation of many harmful substances such as steroid estrogens, 17 $\beta$-estradiol, estriol, 17 $\alpha$-ethinylestradiol, phenolic xenoestrogens, and bisphenol A [22]. The purpose of the conducted research was to determine the removal effectiveness of brominated phenolic compounds present in wastewater from underground coal gasification by means of coagulation-flocculation and $\mathrm{H}_{2} \mathrm{O}_{2} / \mathrm{UV}$ processes. In the first step of the coagulation process, apart from the conventional coagulants, such as $\mathrm{Fe}(\mathrm{II})$, $\mathrm{Fe}(\mathrm{III})$ and $\mathrm{Al}$ salts, we also used $\mathrm{Zr}(\mathrm{IV}), \mathrm{Ti}(\mathrm{IV})$, and anionic flocculant. In the second stage, the $\mathrm{H}_{2} \mathrm{O}_{2} / \mathrm{UV}$ process degraded phenolic compounds remaining in coagulated and flocculated wastewater.

\section{Materials and Methods}

\section{Materials and Chemical Reagents}

The research was carried out on a laboratory scale using post-processing wastewater originating from experimental simulation of the underground coal gasification process conducted in the Barbara Experimental Mine in Mikołów, Poland. Pre-filtered post-processing wastewater was collected in a 1,000-L closed tank to remove coal tar and other insoluble residues. $30 \mathrm{~L}$ of averaged wastewater was collected from the tank in order to carry out the present study. The selected physical and chemical parameters of the wastewater used are shown in Table 1. Ferrous(II) sulphate $\left(\mathrm{FeSO}_{4} \cdot 7 \mathrm{H}_{2} \mathrm{O}\right.$, Chempur, Poland), iron ferric(III) chloride $\left(\mathrm{FeCl}_{3} \cdot 6 \mathrm{H}_{2} \mathrm{O}\right.$, Chempur, Poland), aluminum sulphate $\left(\mathrm{Al}_{2}\left(\mathrm{SO}_{4}\right)_{3} \cdot 18 \mathrm{H}_{2} \mathrm{O}\right.$, Chempur, Poland), zirconium(IV) oxychloride ( $\mathrm{ZrOCl}_{2} \cdot 8 \mathrm{H}_{2} \mathrm{O}, \mathrm{POCH}$, Poland), and titanium(IV) chloride $(1.197 \mathrm{~mol} / \mathrm{L}$ in $\mathrm{HCl})$ were used as coagulants. $30 \% \mathrm{NaOH}$ and $20 \% \mathrm{HCl}$ was used for $\mathrm{pH}$ adjustment, and sediment flocculation was carried out using a solution of $0.025 \%$ anionic flocculant (Furoflock CW277, Chemische Fabrik Wocklum GmbH \& Co. KG, Germany). Filtration after flocculation and sedimentation of sludge was carried out using hard qualitative filters (POCH, Poland). $30 \% \mathrm{H}_{2} \mathrm{O}_{2}$ (Chempur, Poland) was used for advanced oxidation in the $\mathrm{H}_{2} \mathrm{O}_{2} / \mathrm{UV}$ system, and $\mathrm{Na}_{2} \mathrm{SO}_{3}$ ( $\mathrm{POCH}$, Poland) was used to remove the remaining $\mathrm{H}_{2} \mathrm{O}_{2}$. All chemical reagents used in the tests were of analytical purity. Studies using advanced oxidation were carried out by means of a glass $0.6 \mathrm{~L}$ photoreactor equipped with a UV lamp (254 nm) of $11 \mathrm{~W}$ power (PURITEC HNS, OSRAM) housed in a quartz glass casing. The use of a magnetic stirrer enabled mixing of wastewater irradiated at a constant speed of $250 \mathrm{rpm}$, and cooling allowed the tests to be carried out at a constant temperature of $19.0 \pm 1^{\circ} \mathrm{C}$.

\section{Analytical Methods}

The $\mathrm{pH}$-value of wastewater was determined with the use of WTWinolab pH/IONCond 750 and SenTix81 
combination electrode according to PN-EN ISO 10523:2012, and the specific electrical conductivity using TetraCon325 electrode according to PN-EN 27888:1999. Turbidity was determined by the nephelometric method using a Cyberscan IR Turbidimeter TB1000 according to PN-ISO 7027:2003 and color using a SPEKOL 1200 spectrophotometer according to PN-ISO 7887:2012. Absorbance was determined using a Cary 50 UV/VIS spectrophotometer at 1:40 dilution of analysed wastewater (water for HPLC) and using quartz cuvettes with optical path length of $1 \mathrm{~cm}$. Chemical oxygen demand (COD) was determined by spectrophotometric method using sealed tubes and a PF-11 spectrophotometer according to PN-ISO 15705:2005, and total organic carbon (TOC) content according to high temperature combustion at $680^{\circ} \mathrm{C}$ with IR detection using TOC- $\mathrm{L}_{\mathrm{CPH}}$ by Shimadzu according to PN-EN 1484:1999. Sulphides concentration was determined by the spectrophotometric method using the test Visocolor Sulphides 0.1-0.8 mg/L (sulphides/ N,N-dimethyl-1.4-phenylenediamine(III), MachereyNagel GmbH, Germany). Determination of phenols that are brominated in acidic medium at concentrations above $10 \mathrm{mg} / \mathrm{L}$ was carried out by bromometric titration method according to PN-72/C-04602/02. The concentration of the remaining $\mathrm{H}_{2} \mathrm{O}_{2}$ was determined by manganometric method according to PN-72/C-04602/02. The excess of $\mathrm{H}_{2} \mathrm{O}_{2}$, remaining after oxidation and alkalisation was removed using a stoichiometric amount of $10 \% \mathrm{Na}_{2} \mathrm{SO}_{3}$.

\section{Methodology of Research}

A three-step study was conducted on a laboratory scale. In the first stage, the concentration of the following ions: $\mathrm{Fe}(\mathrm{II}), \mathrm{Fe}(\mathrm{III}), \mathrm{Al}, \mathrm{Ti}(\mathrm{IV})$, and $\mathrm{Zr}(\mathrm{IV})$ was tested in the aqueous solution with $\mathrm{pH} 2-10$. For this purpose, sample solutions (acidified with concentrated $\mathrm{HCl}$ ) of each metal used as coagulants with concentration of $100 \mathrm{mg} / \mathrm{L}$ were prepared. Then the $\mathrm{pH}$ was adjusted to a selected value in the range $2-10$ with $30 \% \mathrm{NaOH}$. After stabilizing the $\mathrm{pH}$, it was filtered through a syringe filter to separate the precipitated sludge and the concentration of metal in the filtrate was determined. The purpose of this stage of the study was to determine the $\mathrm{pH}$ value in which the solubility of the precipitated metal hydroxides is the smallest and hence the effectiveness of the coagulant should be the greatest. In the second stage of the study, coagulation of post-processing wastewater was carried out with each coagulant in the amount of $200 \mathrm{mg}$ of $\mathrm{Fe}^{2+}, \mathrm{Fe}^{3+}, \mathrm{Al}^{3+}, \mathrm{Ti}^{4+}$, or $\mathrm{Zr}^{4+} / \mathrm{L}$ at $\mathrm{pH}$ 6.5, 7.5, 8.5, and 9.5. Coagulant was added to the measured amount of wastewater in an appropriate amount so that metal ion concentration was $200 \mathrm{mg} / \mathrm{L}$. Then the $\mathrm{pH}$ was adjusted to a selected value, $0.025 \%$ of anionic flocculant solution in the amount equivalent to $4 \mathrm{ml} / \mathrm{L}$ was added, and phenols, $\mathrm{COD}, \mathrm{UV}_{254}$ absorbance, color, and turbidity in the filtrate were determined. Subsequently, according to the presented methodology, for constant $\mathrm{pH}$ value of 8 and variable doses of coagulants, tests were carried out for the concentration of each metal ion 400-1,000 mg/L (for $\mathrm{Al}^{3+} 200-800 \mathrm{mg} / \mathrm{L}$ due to the formation of large amounts of precipitate). In the third stage of initial coagulation-flocculation with $\mathrm{Al}_{2} \mathrm{SO}_{4} \cdot 18 \mathrm{H}_{2} \mathrm{O}$ as the most effective coagulant $(400 \mathrm{mg}$ $\mathrm{Al}^{3+} / \mathrm{L}, \mathrm{pH} 7.5-8.0$ ), purification was carried out by the method of advanced $\mathrm{H}_{2} \mathrm{O}_{2} / \mathrm{UV}$ oxidation. At this stage, the influence of $\mathrm{H}_{2} \mathrm{O}_{2}$ concentration and exposure time on the phenolic content in oxidized wastewater $(\mathrm{pH}$, UV lamp power, mixing speed, and process temperature adopted as constant) were studied. The $\mathrm{pH} 3$ value at which oxidation was performed was based on the findings of the paper [23]. The effectiveness of post-processing wastewater was studied by means of coagulation-flocculation and combined coagulation-flocculation and advanced $\mathrm{H}_{2} \mathrm{O}_{2} / \mathrm{UV}$ oxidation.

\section{Results and Discussions}

Table 1 shows the results of the post-processing wastewater from the Underground Coal Gasification (UCG) process, which was characterized by slightly alkaline $\mathrm{pH}$ (7.5), trace amounts of sulphides (0.81 mg/L), and slight turbidity (171 NTU). The tested wastewater was intensely brown colored (3320 mg Pt/L) and characterized by high concentrations of organic compounds (COD, TOC, $\mathrm{N}_{\text {total }}$ ), including phenols $(1360 \mathrm{mg} / \mathrm{L})$. The effectiveness of coagulants used for the treatment of industrial and municipal wastewater depends on, among other factors, the $\mathrm{pH}$ at which the coagulation process is carried out. Conducting coagulation process at $\mathrm{pH}$ in which the solubility of the precipitated hydrated metal hydroxides is the smallest usually determines the significant efficiency of the process. Fig. 1 shows the dependence of metal ion concentrations $\left(\mathrm{Fe}^{2+}, \mathrm{Fe}^{3+}, \mathrm{Al}^{3+}, \mathrm{Ti}^{4+}\right.$, and $\left.\mathrm{Zr}^{4+}\right)$ remaining in sedimentation water from the $\mathrm{pH}$ at which the coagulation process was performed (the initial concentration of each metal was $100 \mathrm{mg} / \mathrm{L}$ ). The smallest concentrations of metal ions in the sediment solution over the entire $\mathrm{pH}$ range were obtained for $\mathrm{Ti}^{4+}$ and $\mathrm{Zr}^{4+}$ ions (in the ranges from $0.007-1.20 \mathrm{mg} / \mathrm{L}$ and $0.05-1.05 \mathrm{mg} / \mathrm{L}$, respectively). The lowest concentrations of $\mathrm{Fe}^{2+}$ ions were observed in $\mathrm{pH}$ range $7-10(1.4 \mathrm{mg} / \mathrm{L}$ and $0.021 \mathrm{mg} / \mathrm{L}$, respectively). In the case of $\mathrm{Fe}^{3+}$ ions, the lowest concentrations were recorded

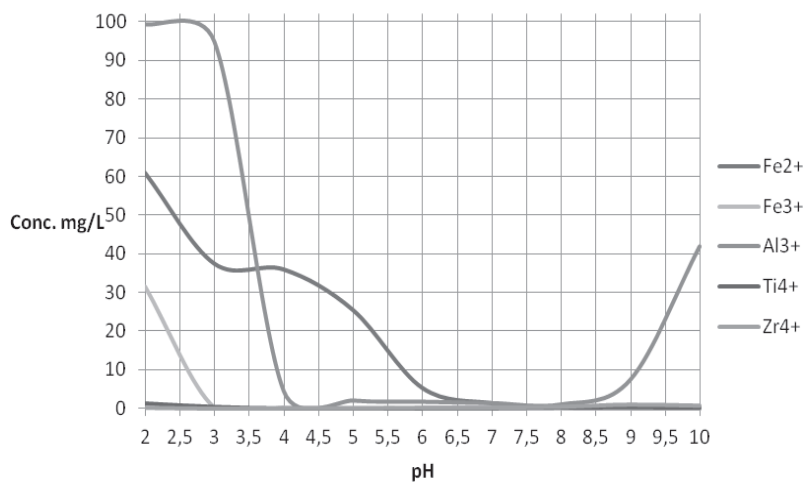

Fig. 1. Effect of $\mathrm{pH}$ on metal ion concentrations. 
Table 2. Physicochemical parameters of post-processing wastewater after the coagulation-flocculation process ( $\mathrm{pH}$ 6.5-9.5, concentration of coagulant calculated on metal $200 \mathrm{mg} / \mathrm{L}$ ).

\begin{tabular}{|c|c|c|c|c|c|}
\hline $\mathrm{pH}$ & Phenols, mg/L & $\mathrm{COD}, \mathrm{mg} \mathrm{O}_{2} / \mathrm{L}$ & $\begin{array}{l}\text { Absorbance, } \mathrm{UV}_{254} \\
\quad \text { (dilution 1:40) }\end{array}$ & Colour, mg Pt/L & Turbidity, NTU \\
\hline \multicolumn{6}{|c|}{$\mathrm{Fe}^{2+}, 200 \mathrm{mg} / \mathrm{L}$} \\
\hline 6.5 & 1146 & 2872 & 0.725 & $>5000$ & 260 \\
\hline 7.5 & 1190 & 2816 & 0.588 & $>5000$ & 300 \\
\hline 8.5 & 1148 & 2836 & 0.264 & 1030 & 15 \\
\hline 9.5 & 1105 & 2856 & 0.396 & 1040 & 15 \\
\hline \multicolumn{6}{|c|}{$\mathrm{Fe}^{3+}, 200 \mathrm{mg} / \mathrm{L}$} \\
\hline 6.5 & 1190 & 2856 & 0.353 & 2230 & 73 \\
\hline 7.5 & 1190 & 2862 & 0.348 & 2070 & 58 \\
\hline 8.5 & 1190 & 2864 & 0.313 & 1710 & 34 \\
\hline 9.5 & 1190 & 2808 & 0.353 & 2020 & 37 \\
\hline \multicolumn{6}{|c|}{$\mathrm{Al}^{3+}, 200 \mathrm{mg} / \mathrm{L}$} \\
\hline 6.5 & 1146 & 2740 & 0.257 & 870 & 15 \\
\hline 7.5 & 1105 & 2720 & 0.259 & 830 & 14 \\
\hline 8.5 & 1105 & 2720 & 0.261 & 820 & 16 \\
\hline 9.5 & 1190 & 2800 & 0.273 & 930 & 19 \\
\hline \multicolumn{6}{|c|}{$\mathrm{Ti}^{4+}, 200 \mathrm{mg} / \mathrm{L}$} \\
\hline 6.5 & 1169 & 2896 & 0.354 & 1340 & 36 \\
\hline 7.5 & 1184 & 2808 & 0.301 & 1090 & 28 \\
\hline 8.5 & 1126 & 2828 & 0.297 & 1080 & 16 \\
\hline 9.5 & 1126 & 2852 & 0.385 & 1530 & 33 \\
\hline \multicolumn{6}{|c|}{$\mathrm{Zr}^{4+}, 200 \mathrm{mg} / \mathrm{L}$} \\
\hline 6.5 & 1169 & 2968 & 0.354 & 1140 & 53 \\
\hline 7.5 & 1169 & 3028 & 0.386 & 2070 & 77 \\
\hline 8.5 & 1169 & 2952 & 0.442 & 3170 & 193 \\
\hline 9.5 & 1169 & 2916 & 0.431 & 3000 & 191 \\
\hline
\end{tabular}

for $\mathrm{pH}>3$ and were $0.2-0.0065 \mathrm{mg} / \mathrm{L}$, whereas at $\mathrm{pH} 2$ the concentration of $\mathrm{Fe}^{3+}$ in sediment solution was $31.5 \mathrm{mg} / \mathrm{L}$.

For aluminum coagulant, the lowest concentrations of $\mathrm{Al}^{3+}$ ions were found in $\mathrm{pH}$ range 4-9, while at $\mathrm{pH} 10$ the concentration of $\mathrm{Al}^{3+}$ was $42 \mathrm{mg} / \mathrm{L}$. The conducted study showed that for $\mathrm{pH}$ between 6.25 and 8.75, the concentration of metal ions in sedimentation water was below $5 \mathrm{mg} / \mathrm{L}$, and at $\mathrm{pH}$ above 8.75 a significant increase in $\mathrm{Al}^{3+}$ concentration was observed. As a consequence, a preliminary study of the effectiveness of the coagulation-flocculation of postprocessing wastewater was conducted at $\mathrm{pH} 6.5,7.5,8 ., 5$ and 9.5 using a dose of each coagulant corresponding to $200 \mathrm{mg} / \mathrm{L} \mathrm{Fe}^{2+}, \mathrm{Fe}^{3+}, \mathrm{Al}^{3+}, \mathrm{Ti}^{4+}$, and $\mathrm{Zr}^{4+}$. The impact of coagulation $\mathrm{pH}$ at constant metal concentration on phenolic content was studied, as well as COD, $\mathrm{UV}_{254}$, color, and turbidity (Table 2).
The use of the mentioned coagulants caused a slight decrease in phenolic concentrations to $1,105-1,190 \mathrm{mg} / \mathrm{L}$ for $\mathrm{Fe}^{2+}$ and $\mathrm{Al}^{3+}$ and $1,126-1,184 \mathrm{mg} / \mathrm{L}$ for $\mathrm{Ti}^{4+}$. In the case of using salts containing $\mathrm{Fe}^{3+}$ and $\mathrm{Zr}^{4+}+$ ions for coagulation, the phenolic concentration values were unchanged in the tested $\mathrm{pH}$ ranges and amounted to 1,190 and $1,169 \mathrm{mg} / \mathrm{L}$, respectively. The coagulationflocculation process enabled the removal from $12.5-18.8 \%$ of the initial amount of phenols equal to $1,360 \mathrm{mg} / \mathrm{L}$. For comparison, other authors in the case of wastewater from the landfill leachate for highly extreme doses of coagulant and cationic flocculant $\left(13.2 \mathrm{~g} / \mathrm{L} 40 \% \mathrm{FeCl}_{3}\right.$ and $62 \mathrm{ml} / \mathrm{L}$ of flocculant) obtained $98 \%$ phenol removal. The initial concentrations of phenol were $241.8 \mathrm{mg} / \mathrm{L}$ [24]. The largest reduction in COD (8.2-10.8\%) was achieved after coagulation of $\mathrm{Al}^{3+}$ ions, while at extreme $\mathrm{pH}$ values (6.5 or 9.5), COD value was 
Table 3. Physicochemical parameters of post-processing wastewater after the coagulation-flocculation process ( $\mathrm{pH} 8$, concentration of coagulant calculated on metal $200-1,000 \mathrm{mg} / \mathrm{L})$.

\begin{tabular}{|c|c|c|c|c|c|}
\hline $\begin{array}{c}\text { Dose of coagulant calculated } \\
\text { to metal }(\mathrm{mg} / \mathrm{L})\end{array}$ & $\begin{array}{l}\text { Phenols } \\
(\mathrm{mg} / \mathrm{L})\end{array}$ & $\begin{array}{c}\mathrm{COD} \\
\left(\mathrm{mg} \mathrm{O}_{2} / \mathrm{L}\right)\end{array}$ & $\begin{array}{l}\text { Absorbance }\left(\mathrm{UV}_{254}\right. \\
\text { dilution } 1: 40)\end{array}$ & $\begin{array}{l}\text { Colour } \\
(\mathrm{mg} \mathrm{Pt} / \mathrm{L})\end{array}$ & Turbidity (NTU) \\
\hline \multicolumn{6}{|c|}{$\mathrm{Fe}^{2+}, \mathrm{pH} 8$} \\
\hline 400 & 1100 & 2704 & 0.274 & 1425 & 58 \\
\hline 600 & 1067 & 2712 & 0.266 & 1590 & 78 \\
\hline 800 & 1058 & 2732 & 0.278 & 3420 & 311 \\
\hline 1000 & 1058 & 2688 & 0.287 & $>5000$ & $>400$ \\
\hline \multicolumn{6}{|c|}{$\mathrm{Fe}^{3+}, \mathrm{pH} 8$} \\
\hline 400 & 1143 & 2724 & 0.267 & 810 & 15 \\
\hline 600 & 1143 & 2756 & 0.256 & 660 & 10 \\
\hline 800 & 1101 & 2756 & 0.254 & 1840 & $<10$ \\
\hline 1000 & 1058 & 2672 & 0.254 & 1240 & $<10$ \\
\hline \multicolumn{6}{|c|}{$\mathrm{Al}^{3+}, \mathrm{pH} 8$} \\
\hline 200 & 1101 & 2616 & 0.253 & 550 & $<10$ \\
\hline 400 & 1143 & 2612 & 0.253 & 580 & $<10$ \\
\hline 600 & 1143 & 2640 & 0.251 & 520 & $<10$ \\
\hline 800 & 1143 & 2812 & 0.267 & 580 & $<10$ \\
\hline \multicolumn{6}{|c|}{$\mathrm{Ti}^{4+}, \mathrm{pH} 8$} \\
\hline 400 & 1083 & 2704 & 0.247 & 500 & $<10$ \\
\hline 600 & 1083 & 2696 & 0.244 & 480 & $<10$ \\
\hline 800 & 1083 & 2720 & 0.246 & 1030 & $<10$ \\
\hline 1000 & 1083 & 2812 & 0.245 & 1130 & $<10$ \\
\hline \multicolumn{6}{|c|}{$\mathrm{Zr}^{4+}, \mathrm{pH} 8$} \\
\hline 400 & 1253 & 2768 & 0.351 & 1030 & 23 \\
\hline 600 & 1211 & 2800 & 0.337 & 910 & 22 \\
\hline 800 & 1126 & 2792 & 0.319 & 830 & 12 \\
\hline 1000 & 1083 & 2680 & 0.283 & 980 & 18 \\
\hline
\end{tabular}

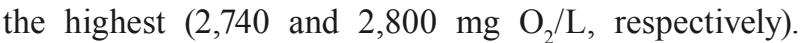
The use of aluminum coagulant also caused a significant decrease in $\mathrm{UV}_{254}(37.4-41.2 \%)$, color (72.0-75.3\%), and turbidity (88.9-91.2\%). In the case of using for coagulation $\mathrm{Fe}^{2+}+$ ions at $\mathrm{pH} 6.5$ and 7.5, the color of treated wastewater intensified $(>5,000 \mathrm{mg}$ $\mathrm{Pt} / \mathrm{L}$ ) and turbidity (260 and $300 \mathrm{NTU}$, respectively) increased. For $\mathrm{Fe}^{3+}, \mathrm{Ti}^{4+}$, and $\mathrm{Zr}^{4+}$ ions, $\mathrm{UV}_{254}$ value, colour, and turbidity were higher in the studied $\mathrm{pH}$ range than for $\mathrm{Al}^{3+}$ ions. In addition, in the case of $\mathrm{Al}^{3+}$, large, well-sedimented sludge flocs (for $\mathrm{pH}$ 6.5, 7.5 and 8.5) were obtained in the flocculation process. In the next step, the efficiency test of the coagulationflocculation process was carried out at $\mathrm{pH} 8$ and using the increasing doses of each coagulant corresponding to $400,600,800$, and $1,000 \mathrm{mg} / \mathrm{L}$ of $\mathrm{Fe}^{2+}, \mathrm{Fe}^{3+}, \mathrm{Ti}^{4+}$, and $\mathrm{Zr}^{4+}$ (for $\mathrm{Al}^{3+} 200-800 \mathrm{mg} / \mathrm{L}$ ). The influence of coagulant (metal ions) dose at constant $\mathrm{pH}$ on phenolic content and additionally on the change in the value of $\mathrm{COD}, \mathrm{UV}_{254}$, color, and turbidity was studied.

The results of our studies are shown in Table 3. The lowest phenol concentrations $(1,058-1,067 \mathrm{mg} / \mathrm{L})$ were observed after using $\mathrm{Fe}^{2+}(600,800$, and $1,000 \mathrm{mg} / \mathrm{L})$, but as the coagulant dose increased, unacceptable increase in $\mathrm{UV}_{254}$ (max. >0.287), color (max. $>500 \mathrm{mg} \mathrm{Pt} / \mathrm{L}$ ), and turbidity (max. $>400 \mathrm{NTU}$ ) took place. The increase in the color value of wastewater was also noted after using high doses of coagulant containing $\mathrm{Fe}^{3+}$ $(1,840$ and $1,240 \mathrm{mg} \mathrm{Pt} / \mathrm{L}$ for 800 and $1,000 \mathrm{mg}$ $\mathrm{Fe}^{3+} / \mathrm{L}$, respectively). Slightly higher values of phenolic concentrations $(1083 \mathrm{mg} / \mathrm{L})$ were obtained when $\mathrm{Ti}^{4+}$ ions were used for the coagulation process, which corresponded to a decrease in $\mathrm{UV}_{254}$ (0.244-0.247) and turbidity $(<10 \mathrm{NTU})$ for all doses. Unfortunately, 


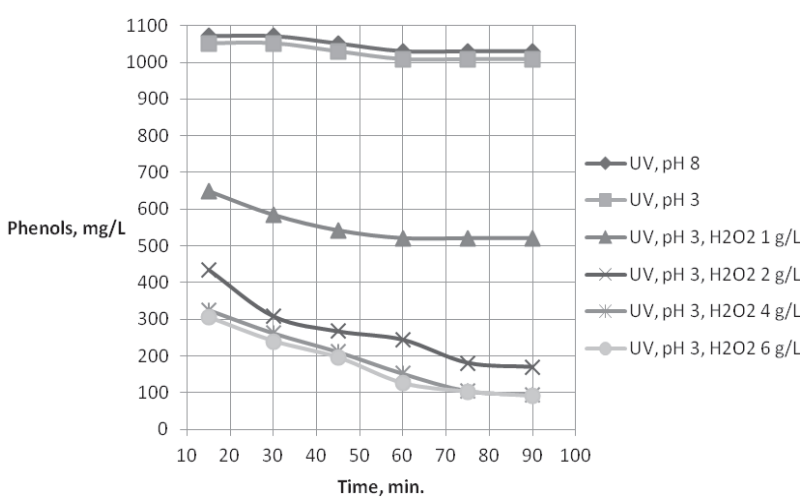

Fig. 2. Effect of time and $\mathrm{H}_{2} \mathrm{O}_{2}$ dose on phenol concentrations.

increasing the coagulant dose also caused an increase in the color value of the treated wastewater (max.

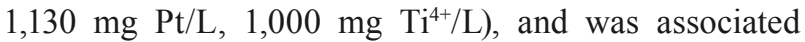
with high consumption of $\mathrm{NaOH}$ for alkalisation of wastewater resulting from the need to use significantly acidified $\mathrm{TiCl}_{4}$ solution to inhibit hydrolysis of $\mathrm{Ti}^{4+}$ ions. When coagulant containing $\mathrm{Al}^{3+}$ ions was used, significant color reductions (82.5-84.3\%) and turbidity $\left(<10\right.$ NTU for each $\mathrm{Al}^{3+}$ dose $)$ were achieved. In addition, the use of aluminium coagulant was associated with the need for a slight $\mathrm{pH}$ adjustment and the formation of a considerable amount of precipitate; however, it consisted of flocks characterized by large size and fast sedimentation.

For $\mathrm{Al}^{3+}$ doses in the range of $200-800 \mathrm{mg} / \mathrm{L}$, similar concentrations of phenols, $\mathrm{COD}, \mathrm{UV}_{254}$, color, and turbidity were obtained. For this reason, it was assumed that the treated wastewater prior to $\mathrm{H}_{2} \mathrm{O}_{2} / \mathrm{UV}$ treatment would be coagulated with an average dose of aluminium coagulant, i.e., $400 \mathrm{mg} \mathrm{Al}^{3+} / \mathrm{L}$ at $\mathrm{pH}$. Therefore 10 one-liter wastewater samples were coagulated, which after averaging by mixing exhibited $\mathrm{pH} 8$ and contained 1,100 $\mathrm{mg} / \mathrm{L}$ of phenols. That wastewater was exposed in a photoreactor and the results of the carried out studies are shown in Fig. 2. $\mathrm{UV}$ irradiation at $\mathrm{pH} 8$ and 3 was associated with slight changes in phenolic concentrations, which varied between 1,073-1,030 and 1,052-1,009 m/L, respectively. Smaller values were reached after $90 \mathrm{~min}$. of UV light exposure, then $\mathrm{H}_{2} \mathrm{O}_{2}$ was added at $1,2,4$, and $6 \mathrm{~g} / \mathrm{L}$. At all doses, the highest rate of reduction of phenolic concentrations was observed up to $60 \mathrm{~min}$. duration of the process, after which the value of phenolic concentration varied only

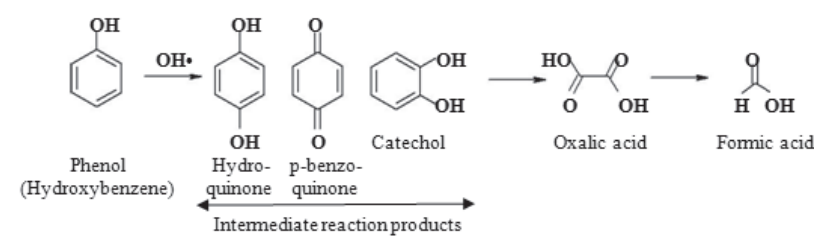

Fig. 3. Degradation of phenol (hydroxybenzene) in aqueous solution $[23,29-30]$. slightly. The highest difference in phenol concentration in treated wastewater was for $\mathrm{H}_{2} \mathrm{O}_{2}$ doses of 1 and $2 \mathrm{~g} / \mathrm{L}$, while the difference was small when 4 and $6 \mathrm{~g} / \mathrm{L}$ $\mathrm{H}_{2} \mathrm{O}_{2}$ was used. Therefore, the use of $\mathrm{H}_{2} \mathrm{O}_{2}$ doses greater than $4 \mathrm{~g} / \mathrm{L}$ in the case of treated wastewater would be technically and economically unjustifiable. Therefore, for the purified wastewater we used the following optimum values for process parameters: $\mathrm{pH} 3, \mathrm{H}_{2} \mathrm{O}_{2}$ concentration $4 \mathrm{~g} / \mathrm{L}$, exposure time 90 minutes, UV lamp power $11 \mathrm{~W}$, mixing speed $250 \mathrm{rpm}$, and temperature $19 \pm 1^{\circ} \mathrm{C}$. Use of the above parameters resulted in a decrease in phenols concentration from $1,100 \mathrm{mg} / \mathrm{L}$ (value after coagulationflocculation) to $95 \mathrm{mg} / \mathrm{L}$ (reduction by $91 \%$ ). Other authors using zeolite obtained $93-100 \%$ reduction of phenol. The degree of phenol removal was dependent on the zeolite dose. In this case phenol is only adsorbed and does not decompose [25]. The application of membrane technique can remove $88 \%$ of phenol, which was separated as a condensed permeate [26]. Other authors also studied the removal of phenol using biological processes in the aerobic bioreactor with glass beads. The phenol removal rate of $89 \%$ was achieved. The application of anaerobic wastewater stabilization pond for phenol removal obtained $90 \%$ of phenol reduction [27-28].

In the presented study, taking into account the initial concentration of phenols in the post-processing wastewater $(1360 \mathrm{mg} / \mathrm{L})$, the use of the coagulationflocculation process $\left(\mathrm{pH} 8,400 \mathrm{mg} \mathrm{Al}^{3+} / \mathrm{L}\right)$ allowed for a decrease in phenolic concentration to $1,100 \mathrm{mg} / \mathrm{L}(19.1 \%)$ and using the processes of coagulation-flocculation and advanced $\mathrm{H}_{2} \mathrm{O}_{2} / \mathrm{UV}$ oxidation, up to $95 \mathrm{mg} / \mathrm{L}$ (93\%). The carried out studies show that phenol degradation in the post-processing wastewater took place in an acidic environment $(\mathrm{pH} 3)$, and the intensity of degradation increased with the increase in $\mathrm{H}_{2} \mathrm{O}_{2}$ dose to $6 \mathrm{~g} / \mathrm{L}$, which affected the amount of $\mathrm{OH} \bullet$ radicals formed per unit time. Intermediate phenol products identified and characterized in the literature, such as hydroquinone, p-benzoquinone and catechol, indicate that $\mathrm{OH} \bullet$ radicals are involved in phenol decomposition, as schematically shown in Fig. 3 [29-30].

\section{Conclusions}

Our paper presents results of research on phenol removal from wastewater originating from an experimental simulation of the underground coal gasification process conducted in the Barbara Experimental Mine in Mikołów, Poland. By means of the coagulation-flocculation process carried out with the use of coagulants containing $\mathrm{Fe}^{2+}, \mathrm{Fe}^{3+}, \mathrm{Al}^{3+}, \mathrm{Ti}^{4+}$, and $\mathrm{Zr}^{4+}$ salts, a slight decrease in phenolic concentrations ranging from $7.9 \%\left(\mathrm{pH} 8, \mathrm{Zr}^{4+} 400 \mathrm{mg} / \mathrm{L}\right)$ to $22.2 \%$ (for $\mathrm{pH} 8, \mathrm{Fe}^{2+} 800$ and 1,000 mg/L, and $\mathrm{pH} 8$, $\left.\mathrm{Fe}^{3+} 1,000 \mathrm{mg} / \mathrm{L}\right)$ was obtained. Applying combined coagulation-flocculation processes $\left(\mathrm{Al}^{3+} 400 \mathrm{mg} / \mathrm{L}\right.$, $\mathrm{pH}$ 8) and advanced $\mathrm{H}_{2} \mathrm{O}_{2} / \mathrm{UV}$ oxidation ( $\mathrm{pH} \mathrm{3}, \mathrm{H}_{2} \mathrm{O}_{2}$ $4 \mathrm{~g} / \mathrm{L}$, UV exposure time of 90 minutes, UV power 
of $11 \mathrm{~W}$, mixing speed $250 \mathrm{rpm}, 19 \pm 1^{\circ} \mathrm{C}$ ), resulted in a total reduction of phenolic concentration in the treated wastewater by about $93 \%$ due to their reaction with $\mathrm{OH} \bullet$ radical ions resulting from the impact of UV radiation on $\mathrm{H}_{2} \mathrm{O}_{2}$.

\section{References}

1. SARAVANAKUMAR K., KUMAR A. Removal of phenol from aqueous solution by adsorption using zeolite. African Journal of Agricultural Research, 8 (23), 2965, 2013.

2. CONTRERASA S., RODRIGUEZ M., AL MOMANIA F., SANS C., ESPLUGAS S. Contribution of the ozonation pre-treatment to the biodegradation of aqueous solutions of 2,4- dichlorophenol. Water Research 37, 3164, 2003.

3. BUSCA G., BERARDINELLI S., RESINI C., ARRIGHI L. Technologies for the removal of phenol from fluid streams: A short review of recent developments. Journal of Hazardous Materials 160, 265, 2008.

4. KAPUSTA K., STAŃCZYK K. Pollution of water during underground coal gasification of hard coal and lignite. Fuel, 90, 1927, 2011.

5. KAPUSTA K., STAŃCZYK K., WIATOWSKI M., CHEĆKO J. Environmental aspects a field-scale underground coal gasification trial in a shallow coal seam at the Experimental Mine Barbara in Poland, Fuel, 113, 196, 2013.

6. KAPUSTA K., STAŃCZYK K. Chemical and toxicological evaluation of underground coal gasification (UCG) effluents. The coal rank effect. Ecotoxicology and Environmental Safety, 112, 105, 2015.

7. FAROOK A., ANDAS J., AB.RAHMAN I. A study on the oxidation of phenol by heterogeneous iron silica catalyst. Chemical Engineering Journal, 165 (2), 658, 2010.

8. YANG J., ZHOU M., ZHAO Y., ZHANG, CH., HU Y. Electrosorption driven by microbial fuel cells to remove phenol without external power supply. Bioresource Technology, 150, 271, 2013.

9. United States Environmental Protection Agency, U.S. EPA, https://nepis.epa.gov/Adobe/PDF/2000LNAI.PDF (03.05.2017).

10. ZHOU J., YU X., DING C., WANG Z., ZHOU Q., PAO H., CAI W. Optimization of phenol degradation by Candida tropicalis Z-04 using Plackett-Burman design and response surface methodology. Journal of Environmental Sciences, 23, (1), 22, 2011.

11. PARK H., KODURU J.R., CHOO K., LEE B. Activated carbons impregnated with iron oxide nanoparticles for enhanced removal of Bisphenol A and natural organic matter. Journal of Hazardous Materials, 286, 315, 2015.

12. MASOMI M., GHOREYSHI A.A., NAJAFPOUR G.D., MOHAMED A.R.B. Adsorption of phenolic compounds onto the activated carbon synthesized from pulp and paper mill sludge: equilibrium isotherm, kinetics, thermodynamics and mechanism studies. International Journal of Engineering. Transactions A. Basics, 27 (10), 1485, 2014.

13. LIU J., XIE J., REN Z., ZHANG W. Solvent extraction of phenol with cumene from wastewater. Desalination and Water Treatment, 51, 3826, 2013.

14. MNIF A., TABASSI D., ALI M.B.S., HAMROUN B. Phenol removal from water by AG reverse osmosis membrane. Environmental Progress \& Sustainable Energy, 34, 982, 2015.

15. KUMAR R., PAL P. Removal of phenol from coke-oven wastewater by cross-flow nanofiltration membranes. Water Environment Research, 85 (5), 447, 2013.

16. WU Y., TIAN G., TAN H., FU X. Pervaporation of phenol wastewater with PVDF-PU blend membrane. Desalination and Water Treatment, 51, 5311, 2013.

17. MOHAMMADI T., KAZEMI P. Taguchi optimization approach for phenolic wastewater treatment by vacuum membrane distillation. Desalination and Water Treatment. 52, 1341, 2014.

18. YATES B.J., ZBORIL R., SHARMA V.K. Engineering aspects of ferrate in water and wastewater treatment-a review. Journal of Environ Science \& Health Part A: Toxic/Hazardous Substances and Environmental Engineering, 49 (14), 1603, 2014.

19. GUAN X., HE D., MA J., CHEN G. Application of permanganate in the oxidation of micropollutants: a mini review. Frontiers of Environmental Science \& Engineering, 4 (4), 405, 2010.

20. CHEN C. Wet air oxidation and catalytic wet air oxidation for refinery spent caustics degradation. Journal of the Chemical Society of Pakistan, 35 (2), 244, 2013.

21. HADJLTAIEF H.B., ZINA M.B., GALVEZ M.E., COSTA P.D. Photo-Fenton oxidation of phenol over a $\mathrm{Cu}$-doped Fe-pillared clay. Comptes Rendus Chimie, 18 (10), 1161, 2015.

22. ZHANG A., LI Y. Removal of phenolic endocrine disrupting compounds from waste activated sludge using $\mathrm{UV}, \mathrm{H}_{2} \mathrm{O}_{2}$ and $\mathrm{UV} / \mathrm{H}_{2} \mathrm{O}_{2}$ oxidation processes. Effects of reaction conditions and sludge matrix. Science of the Total Environment, 493, 307, 2014.

23. CHUNDE W., XINHUI L., DONGBIN W., JINCHU F., LIANSHENG W. Photosonochemical Degradation of Phenol in Water. Water Research, 35, 3927, 2001.

24. BAKRAOUY H., SOUABI S., DIGUA K., PALA A. Removal of phenol and surfactant from landfill leachate by coagulation-flocullation process. Chemistry \& Chemical Engineering, Biotechnology, Food Industry, 16 (4), 329, 2015.

25. SARAVANAKUMAR K., KUMAR A. Removal of phenol from aqueous solution by adsorption using zeolite. African Journal of Agricultural Research, 8 (23), 2965, 2013.

26. GUPTA T., PRADHAN N.C., ADHIKARI B. Synthesis and performance of a novel polyurethaneurea as pervaporation membrane for the selective removal of phenol from industrial waste water. Bulletin of Materials Science, $\mathbf{2 5}$ (6), 533, 2002.

27. DEY S., MUKHERJEE S. Kinetic Studies for an Aerobic Packed Bed Biofilm Reactor for Treatment of Organic Wastewater with and without Phenol, Journal of Water Resource and Protection, 2, 731, 2010.

28. ALMASI A., PIRSAHEB M., DARGAHI A. The Efficiency of Anaerobic Wastewater Stabilization Pond in Removing Phenol from Kermanshah Oil Refinery Wastewater, Iranian Journal of Health and Environment, 5 (1), 41, 2012.

29. NAFFRECHOUX E., CHANOUX S., PETRIER C., SUPTIL J. Sonochemical and photochemical oxidation of organic matter. Ultrasonics Sonochemistry 7 (4), 255, 2000.

30. NAMIEŚNIK J., CHRZANOWSKI W., SZPINEK P. New horizons and challenges in analytics and environmental monitoring, CEERM, Gdańsk, 776, 2003. 
